\section{Ophthalmological and intracranial anomalies in patients with clinical anophthalmos}

\begin{abstract}
Purpose To better describe the clinical and neuroimaging spectrum of abnormalities in clinical anophthalmos.

Methods We performed a retrospective review of all 17 patients admitted to the King Khaled Eye Specialist Hospital with clinical anophthalmos over a 15 year period who had a complete ophthalmological examination documented and received computed tomographic $(\mathrm{CT})$ imaging of the orbits and brain.

Results Patients with clinical anophthalmos had a high incidence of developmental abnormalities involving both eyes (15/17 patients, $88 \%$ ), the brain (12/17 patients, $71 \%$ ) and the body $(7 / 12,58 \%)$. The incidence of central nervous system anomalies reached $100 \%$ in patients with bilateral small optic nerves on CT scan.

Conclusions Patients with clinical

anophthalmos share a similar constellation of neurological, somatic and neuroradiological abnormalities as patients with microphthalmos, septo-optic dysplasia and clinical optic nerve hypoplasia. This fact may provide insight into developmental abnormalities of the afferent visual system and brain.
\end{abstract}

C. Jacquemin

Radiology Department King Khaled Eye Specialist Hospital

Riyadh, Saudi Arabia

\section{P.B. Mullaney}

Pediatrics Division

King Khaled Eye Specialist Hospital

Riyadh, Saudi Arabia

\section{T.M. Bosley}

Neuro-Ophthalmology

Division

King Khaled Eye Specialist

Hospital

Riyadh, Saudi Arabia

Thomas M. Bosley, MD King Khaled Eye Specialist Hospital

PO Box 7191

Riyadh 11462, Kingdom of Saudi Arabia

Tel: +96614821234

Fax: +1 2158933854

e-mail:

tmbosley@bosleynet.net

Proprietary interest: None

Research funding: None

Received: 23 March 1999 Accepted without revision: 17 August 1999
Key words Anophthalmos, Coloboma, Developmental anomaly, Dysgenesis, Microphthalmos, Optic nerve hypoplasia, Septo-optic dysplasia

Anophthalmos involves developmental failure of one or both optic vesicles during the period between the second and sixth week of gestation ${ }^{1}$ in a clinically and genetically heterogeneous group of disorders. ${ }^{2}$ The spectrum of clinical anophthalmos includes severe microphthalmos, in which small amount of ocular tissue can be found in the orbit on neuroimaging even though the globe may appear to be absent externally. ${ }^{3}$ Many microphthalmos patients have additional congenital ocular anomalies ${ }^{2,4}$ and associated neurological and somatic abnormalities. ${ }^{1,5-7}$ but there has been no major description of neuroimaging changes associated with anophthalmos and severe
CLAUDE JACQUEMIN

PAUL B. MULLANEY,

THOMAS M. BOSLEY microphthalmos. Therefore, we reviewed patients admitted to the King Khaled Eye Specialist Hospital in Saudi Arabia with clinical anophthalmos over a 15 year period to confirm the ophthalmological spectrum of this problem and to investigate the incidence of associated central nervous system (CNS) anomalies.

\section{Materials and methods}

Using hospital and physician records, we retrospectively reviewed the medical records of all patients admitted to the King Khaled Eye Specialist Hospital between January 1982 and December 1996 with the diagnosis of clinical unilateral or bilateral anophthalmos. Every child was included in this report whose chart documented a full examination of both eyes and who had computed tomographic (CT) and/or magnetic resonance imaging (MRI) scanning of brain and orbits.

CT scanning of the orbits and suprasellar cistern was performed in the axial plane at $1.5 \mathrm{~mm}$ or $3.0 \mathrm{~mm}$ intervals while images of the brain were obtained with a slice thickness of $5.0 \mathrm{~mm}$ in the posterior fossa and $10.0 \mathrm{~mm}$ through the cerebral hemispheres. Children less than 6 years old were scanned under chloral hydrate sedation after parental consent. Three patients (2,13 and 16) had an MRI examination as well. Optic nerve and globe dimensions were measured using accepted criteria. ${ }^{8,9}$ An optic nerve was considered small if it measured less than $2.5 \mathrm{~mm}$ in transaxial diameter in its midorbital portion. Globe and remnant globe size were assessed by measuring the largest transverse diameter, with a globe considered abnormally small with a diameter $<10 \mathrm{~mm}$ and abnormally large with a diameter $>22 \mathrm{~mm}$. The intracranial space was evaluated for structural anomalies commonly encountered in mild forms of holoprosencephaly and septo-optic dysplasia (SOD), such as those involving the septum pellucidum (present vs absent), corpus callosum (normal vs abnormal, missing or partially missing), cerebral white matter (normal vs moderately or severely hypoplastic), ${ }^{10}$ pituitary gland (normal vs evidence of ectopia) and lateral ventricles (normal vs enlarged). 
Each patient was examined by a paediatrician for somatic developmental abnormalities. Eight patients had hormonal testing (growth hormone, adrenocorticotrophic hormone, prolactin, cortisol and thyroid function tests). Two patients had electroretinograms performed on a Nicolet CA1000 machine using standard technique.

\section{Results}

Table 1 details demographic, clinical and orbital CT information for the 17 patients ( 7 males, 10 females; age range 1 week to 19 years; modal age 9 months) included in this review. All clinically anophthalmic eyes had CT evidence of a vestigial globe (size 1-7 mm; average $2.8 \mathrm{~mm}$ ) and optic nerve in the orbit (Fig. 1a).

Based on CT examinations, patients were placed into one of three categories of decreasing severity of radiological changes. Group 1 included 7 patients who had bilateral severe microphthalmos; group 2 included 5 patients who had unilateral severe microphthalmos and bilateral small optic nerves; and group 3 consisted of 5 patients with unilateral severe microphthalmos and a normal-appearing optic nerve on the contralateral side. No patient had pathological brain calcifications.
Seven patients had somatic anomalies documented, while 9 had obvious clinical neurological abnormalities. Two children had elevated prolactin levels, with normal levels of other tested hormones. Two patients had abnormal electroretinograms.

Table 2 records the results of brain neuroimaging studies in the three categories of patients. All patients in groups 1 and 2 had CNS anomalies on CT scan (Fig. 1a, b; Fig. 2a, b), but no intracranial abnormalities were found in group 3 (Fig. 3a). CNS anomalies included a large optochiasmatic cistern (not explained only by hypoplastic chiasm; 12 patients), partial or total absence of the corpus callosum (9 patients) and/or absent septum pellucidum (4 patients). ${ }^{11}$ White matter hypoplasia was present in 10 patients (8 severe and 2 moderate), predominantly affecting the frontal and temporal lobes (Fig. 1b). Certain ophthalmological abnormalities were well demonstrated by $\mathrm{CT}$ as well as clinical examination (Fig. 3a, b). Two patients (patients 13 and 17) had one globe and optic nerve that were radiologically normal. Seven of 9 patients observed to have clinical neurological abnormalities also had radiological CNS anomalies; 5 additional patients had CNS anomalies on neuroimaging without documented clinical neurological abnormalities.

Table 1(a). Clinical, laboratory and orbital radiological observations

\begin{tabular}{|c|c|c|c|c|c|c|c|c|}
\hline \multirow{2}{*}{$\begin{array}{l}\text { Group } \\
\text { no. }\end{array}$} & \multirow{2}{*}{$\begin{array}{l}\text { Patient } \\
\text { no. }\end{array}$} & \multirow[b]{2}{*}{ Age } & \multirow[b]{2}{*}{ Sex } & \multicolumn{2}{|c|}{ Clinical impression } & \multicolumn{2}{|c|}{ Visual acuity } & \multirow{2}{*}{$\begin{array}{l}\text { Neurological } \\
\text { abnormalities }\end{array}$} \\
\hline & & & & OD & OS & OD & OS & \\
\hline \multirow[t]{7}{*}{1} & 1 & $1 \mathrm{wk}$ & $\mathrm{F}$ & Anophthalmos & Anophthalmos & NLP & NLP & NA \\
\hline & 2 & $2 \mathrm{mo}$ & $\mathrm{F}$ & Anophthalmos & Anophthalmos & NLP & NLP & NA \\
\hline & 3 & $4 \mathrm{mo}$ & M & Anophthalmos & Anophthalmos & NLP & NLP & Delayed milestones \\
\hline & 4 & $7 \mathrm{mo}$ & $\mathrm{F}$ & Anophthalmos & Anophthalmos & NLP & NLP & Delayed milestones \\
\hline & 5 & $9 \mathrm{mo}$ & M & Anophthalmos & Anophthalmos & NLP & NLP & NA \\
\hline & 6 & $10 \mathrm{mo}$ & $\mathrm{F}$ & Anophthalmos & Anophthalmos & NLP & NLP & $\begin{array}{l}\text { Hypotonic; delayed } \\
\text { milestones }\end{array}$ \\
\hline & 7 & $48 \mathrm{mo}$ & $\mathrm{F}$ & Anophthalmos & Anophthalmos & NLP & NLP & Unsteady gait; mute \\
\hline \multirow[t]{5}{*}{2} & 8 & $2 \mathrm{wk}$ & $\mathrm{F}$ & Optic disc coloboma & Anopthalmos & $\mathrm{F}$ and $\mathrm{F}$ & NLP & $\begin{array}{l}\text { Manifest latent } \\
\text { nystagmus }\end{array}$ \\
\hline & 9 & $6 \mathrm{mo}$ & $\mathrm{F}$ & $\begin{array}{l}\text { Microcornea; } \\
\text { sclerocornea }\end{array}$ & Anophthalmos & NLP & NLP & NA \\
\hline & 10 & $7 \mathrm{mo}$ & M & $\begin{array}{l}\text { Iris coloboma; partial } \\
\text { sclerocornea }\end{array}$ & Anophthalmos & $\mathrm{F}$ and $\mathrm{F}$ & NLP & Delayed milestones \\
\hline & 11 & $8 \mathrm{mo}$ & $\mathrm{F}$ & Anophthalmos & $\begin{array}{l}\text { Aniridia; } \\
\text { disorganised cornea; } \\
\text { optic nerve } \\
\text { hypoplasia }\end{array}$ & NLP & NLP & Delayed milestones \\
\hline & 12 & $12 \mathrm{mo}$ & M & Cryptophthalmos & Anophthalmos & NLP & NLP & NA \\
\hline \multirow[t]{5}{*}{3} & 13 & $1 \mathrm{mo}$ & $\mathrm{F}$ & Anophthalmos & Normal & NLP & $\mathrm{F}$ and $\mathrm{F}$ & NA \\
\hline & 14 & $60 \mathrm{mo}$ & M & Anophthalmos & $\begin{array}{l}\text { Iris and optic disc } \\
\text { coloboma }\end{array}$ & NLP & $\mathrm{F}$ and $\mathrm{F}$ & Mental retardation \\
\hline & 15 & $72 \mathrm{mo}$ & M & $\begin{array}{l}\text { Microcornea; inferior } \\
\text { colobomas of iris, } \\
\text { optic disc and } \\
\text { chorioretina }\end{array}$ & Anophthalmos & CF & NLP & $\begin{array}{l}\text { Horizontal and vertical } \\
\text { pendular nystagmus }\end{array}$ \\
\hline & 16 & $78 \mathrm{mo}$ & $\mathrm{F}$ & Anophthalmos & $\begin{array}{l}\text { Optic nerve } \\
\text { coloboma }\end{array}$ & NLP & $20 / 200$ & $\begin{array}{l}\text { Delayed milestones; } \\
\text { horizontal pendular } \\
\text { nystagmus }\end{array}$ \\
\hline & 17 & $19 \mathrm{yr}$ & $\mathrm{F}$ & Normal & Anophthalmos & $20 / 20$ & NLP & NA \\
\hline
\end{tabular}

$\mathrm{OD}$, right eye; OS, left eye; mo, months; wk, weeks; yr, years; NLP, no light perception (by report or behavioural observation); F and F, fix and follow; $\mathrm{CF}$, count fingers; NA, not applicable. 
Table 1(b). Clinical, laboratory and orbital radiological observations (contd)

\begin{tabular}{|c|c|c|c|c|c|c|c|}
\hline \multirow{2}{*}{$\begin{array}{c}\text { Group } \\
\text { no. }\end{array}$} & \multirow{2}{*}{$\begin{array}{c}\text { Patient } \\
\text { no. }\end{array}$} & \multirow{2}{*}{$\begin{array}{l}\text { Somatic } \\
\text { anomalies }\end{array}$} & \multirow{2}{*}{$\begin{array}{l}\text { Laboratory } \\
\text { testing }\end{array}$} & \multirow{2}{*}{$\begin{array}{l}\text { Family } \\
\text { history }\end{array}$} & \multicolumn{2}{|c|}{ Globe size $(\mathrm{mm})$} & \multirow[b]{2}{*}{ Orbital CT results } \\
\hline & & & & & OD & OS & \\
\hline \multirow[t]{7}{*}{1} & 1 & & & None & 7 & 5 & $\begin{array}{l}\text { Microphthalmos OU; } \\
\text { small optic nerves OU }\end{array}$ \\
\hline & 2 & & Normal hormones & $\begin{array}{l}\text { Intermarriage; } \\
\text { grandfather blind }\end{array}$ & $<1$ & $<1$ & $\begin{array}{l}\text { Microphthalmos OU; } \\
\text { small optic nerves OU }\end{array}$ \\
\hline & 3 & & Normal hormones & Intermarriage & $<1$ & $<1$ & $\begin{array}{l}\text { Microphthalmos OU; } \\
\text { small optic nerves OU }\end{array}$ \\
\hline & 4 & & & $\begin{array}{l}\text { None; amoxicillin in } \\
\text { first trimester }\end{array}$ & 1 & 1 & $\begin{array}{l}\text { Microphthalmos OU; } \\
\text { small optic nerves OU }\end{array}$ \\
\hline & 5 & $\begin{array}{l}\text { Abnormal closure of } \\
\text { frontal bones }\end{array}$ & & None & 2 & 1 & $\begin{array}{l}\text { Microphthalmos OU; } \\
\text { small optic nerves OU }\end{array}$ \\
\hline & 6 & & $\begin{array}{l}\text { Elevated prolactin; } \\
\text { otherwise normal } \\
\text { hormones }\end{array}$ & Intermarriage & $<1$ & $<1$ & $\begin{array}{l}\text { Microphthalmos OU; } \\
\text { small optic nerves OU }\end{array}$ \\
\hline & 7 & & & None & 3 & 2 & $\begin{array}{l}\text { Microphthalmos OU; } \\
\text { small optic nerves OU }\end{array}$ \\
\hline \multirow[t]{5}{*}{2} & 8 & & Normal hormones & None & 19 & 6 & $\begin{array}{l}\text { Right globe with deep } \\
\text { anterior chamber; left } \\
\text { microphthalmos; small } \\
\text { optic nerves OU }\end{array}$ \\
\hline & 9 & & & Intermarriage & 19 & $<2$ & $\begin{array}{l}\text { Right large globe with flat } \\
\text { appearance of anterior } \\
\text { segment; left } \\
\text { microphthalmos; small } \\
\text { optic nerves OU }\end{array}$ \\
\hline & 10 & Hip dislocation & & $\begin{array}{l}\text { Intermarriage; } 10 \\
\text { normal siblings }\end{array}$ & 20 & 3 & $\begin{array}{l}\text { Right large globe with } \\
\text { small optic nerve head } \\
\text { coloboma; left } \\
\text { microphthalmos; small } \\
\text { optic nerves OU }\end{array}$ \\
\hline & 11 & Fusion of toes & Flat ERG OS & $\begin{array}{l}\text { Intermarriage; } 2 \\
\text { cousins with } \\
\text { anophthalmos }\end{array}$ & 1.5 & 18 & $\begin{array}{l}\text { Right microphthalmos; } \\
\text { left globe with high } \\
\text { density c/w PHPV; small } \\
\text { optic nerves OU }\end{array}$ \\
\hline & 12 & Fusion of two fingers & Normal hormones & Intermarriage & $30 \times 50$ & 6 & $\begin{array}{l}\text { Right globe enlarged with } \\
\text { deep anterior chamber; } \\
\text { left microphthalmos; } \\
\text { small optic nerves OU }\end{array}$ \\
\hline \multirow[t]{5}{*}{3} & 13 & $\begin{array}{l}\text { Fusion of toes } \\
\text { bilaterally }\end{array}$ & $\begin{array}{l}\text { Elevated prolactin; } \\
\text { otherwise normal } \\
\text { hormones }\end{array}$ & $\begin{array}{l}\text { Intermarriage; } \\
\text { brother, cousin with } \\
\text { anophthalmos }\end{array}$ & 4 & 22 & $\begin{array}{l}\text { Right microphthalmos } \\
\text { with small optic nerve; } \\
\text { normal left globe and } \\
\text { optic nerve }\end{array}$ \\
\hline & 14 & $\begin{array}{l}\text { Ear malformations; } \\
\text { right hammer toe }\end{array}$ & & $\begin{array}{l}\text { Intermarriage; sister } \\
\text { with multiple } \\
\text { anomalies }\end{array}$ & 3 & $21 \times 25$ & $\begin{array}{l}\text { Right microphthalmos } \\
\text { with small optic nerve; } \\
\text { left large globe with } \\
\text { normal optic nerve }\end{array}$ \\
\hline & 15 & & & None & 21 & 2 & $\begin{array}{l}\text { Right optic disc coloboma } \\
\text { with normal optic nerve; } \\
\text { left microphthalmos with } \\
\text { small optic nerve }\end{array}$ \\
\hline & 16 & Cleft palate and lip & $\begin{array}{l}\text { Normal hormones; } \\
\text { abnormal scotopic } \\
\text { ERG }\end{array}$ & None & 2 & 21 & $\begin{array}{l}\text { Right microphthalmos } \\
\text { with small optic nerve; } \\
\text { normal left globe and } \\
\text { optic nerve }\end{array}$ \\
\hline & 17 & & Normal hormones & None & 20 & 1 & $\begin{array}{l}\text { Normal right globe and } \\
\text { optic nerve; left } \\
\text { microphthalmos with } \\
\text { small optic nerve }\end{array}$ \\
\hline
\end{tabular}

OD, right eye; OS, left eye; OU, both eyes; ERG, electroretinogram; intermarriage, parents were first or second cousins; PHPV, persistent hyperplastic primary vitreous.

\section{Discussion}

The ophthalmological examinations reported here are similar to those reported previously in patients with clinical anophthalmos and microphthalmos, ${ }^{1}$ including the frequent presence of bilateral ocular developmental anomalies. The current study confirms the importance of a careful clinical evaluation of both eyes in the setting of clinical anophthalmos or severe microphthalmos because 
Table 2. Intracranial observations

\begin{tabular}{|c|c|c|c|c|c|c|}
\hline $\begin{array}{l}\text { Group } \\
\text { no. }\end{array}$ & $\begin{array}{l}\text { Patient } \\
\text { no. }\end{array}$ & $\begin{array}{l}\text { White matter } \\
\text { hypoplasia }\end{array}$ & $\begin{array}{l}\text { Abnormal corpus } \\
\text { callosum }\end{array}$ & $\begin{array}{l}\text { Abnormal septum } \\
\text { pellucidum }\end{array}$ & $\begin{array}{c}\text { Abnormal } \\
\text { pituitary fossa }\end{array}$ & $\begin{array}{c}\text { Abnormal } \\
\text { optochiasmatic cistern }\end{array}$ \\
\hline \multirow[t]{7}{*}{1} & 1 & ++ & + & + & - & + \\
\hline & 2 & ++ & + & + & - & + \\
\hline & 3 & ++ & + & + & - & + \\
\hline & 4 & ++ & + & + & - & + \\
\hline & 5 & - & + & - & + & + \\
\hline & 6 & + & + & - & - & + \\
\hline & 7 & - & + & - & - & + \\
\hline \multirow[t]{5}{*}{2} & 8 & ++ & + & + & - & + \\
\hline & 9 & ++ & - & - & - & + \\
\hline & 10 & + & - & - & - & + \\
\hline & 11 & ++ & - & - & - & + \\
\hline & 12 & ++ & + & - & - & + \\
\hline \multirow[t]{5}{*}{3} & 13 & - & - & - & - & - \\
\hline & 14 & - & - & - & - & - \\
\hline & 15 & - & - & - & - & - \\
\hline & 16 & - & - & - & - & - \\
\hline & 17 & - & - & - & - & - \\
\hline
\end{tabular}

only 2 of 34 eyes were free of developmental anomalies. Some of the fellow eye anomalies required careful ophthalmological attention and continued treatment in order to maximise residual vision.

All patients with bilateral small optic nerves (groups 1 and 2) had neuroimaging evidence of CNS abnormalities and, conversely, every patient with CNS anomalies on neuroimaging had bilateral small optic nerves. This strong association between severe microphthalmos, bilateral small optic nerves and CNS anomalies in our study population may well reflect a common type of pathological insult for these abnormalities of the developing afferent visual system and brain. $\mathrm{SOD}^{10}$ and clinical optic nerve hypoplasia ${ }^{12}$ are known to occur together in association with brain and body anomalies. The neuroimaging abnormalities reported here are very similar to the CNS disturbances reported in optic nerve hypoplasia and SOD, ${ }^{10,12}$ with the singular exception that schizencephaly did not occur in our patients.

The cranial structures discussed here develop over a long period of gestation. Optic vesicles develop between 2 and 6 weeks, followed by optic nerves (after 2 months), corpus callosum (between 8 and 20 weeks) ${ }^{13}$ and hemispheric white matter (second half of gestation extending into the postnatal period). ${ }^{2}$ Clinical anophthalmos or microphthalmos would be the most obvious outcome if a developmental insult occurred early and targeted appropriate cell populations in the optic vesicle, neural crest or somatomeres, disrupting dynamic interactions both within mesenchymal cell populations and between them and adjacent epithelium. ${ }^{14}$ This was probably the case for the 5 patients in group 3 who had anomalies of the globes with no anatomical abnormality on CT scanning of the brain. A developmental insult acting over a longer period of time or on a broader cell population might combine severe microphthalmos with small optic nerves, midline structural abnormalities and abnormalities of hemispheric white matter, as in our groups 1 and 2 .
Injuries occurring somewhat later in gestation might spare the optic vesicle but cause clinical optic nerve hypoplasia with or without SOD and white matter developmental problems. ${ }^{10,12}$ Similarly, schizencephaly would probably be the result of a focal brain insult acting during the gestational period of neuronal migration, 15 which occurs after development of the optic vesicle (therefore probably sparing the globe) but during the developmental phases of the optic nerve and certain other brain midline structures (therefore potentially causing SOD and optic nerve hypoplasia). This continuum of development may explain why no patient in the current study had schizencephaly, as opposed to almost half of all patients with optic nerve hypoplasia and SOD. ${ }^{10,12}$ Seven of the patients reviewed here had associated somatic abnormalities. These patients may demonstrate the oculo-auriculo-vertebral spectrum of disorders ${ }^{16}$ in which neural crest migration problems cause ocular anomalies together with anomalies of branchial arches I and II such as facial clefts and somatic developmental defects.

Our patients, like those of Tucker et al., ${ }^{1}$ probably fall into the category of sporadic microphthalmos/ anophthalmos with unknown aetiology ${ }^{2}$ even though this institution serves an Arabic population with a high incidence of consanguinity ( $9 / 17$ patients in this study had parents who were first or second cousins). Consanguinity could affect the genetics of the defects described here, but the fact that only 17 patients were identified in this major referral centre over a period of 15 years would speak against a substantially higher incidence than normal.

Neuroimaging does not always reveal clinically apparent CNS abnormalities in microphthalmos, optic nerve hypoplasia and SOD. ${ }^{6,17}$ Only 3 of our patients had an MRI examination, which is superior to CT scanning for certain problems, particularly pituitary and hypothalamic anomalies ${ }^{18}$ with or without hypothalamohypophyseal axis dysfunction. ${ }^{19,20}$ However, CT 


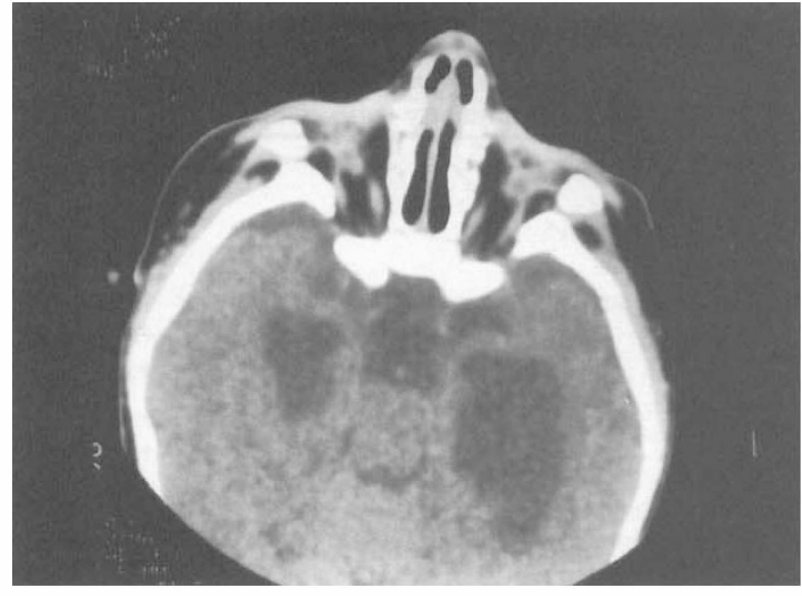

(a)

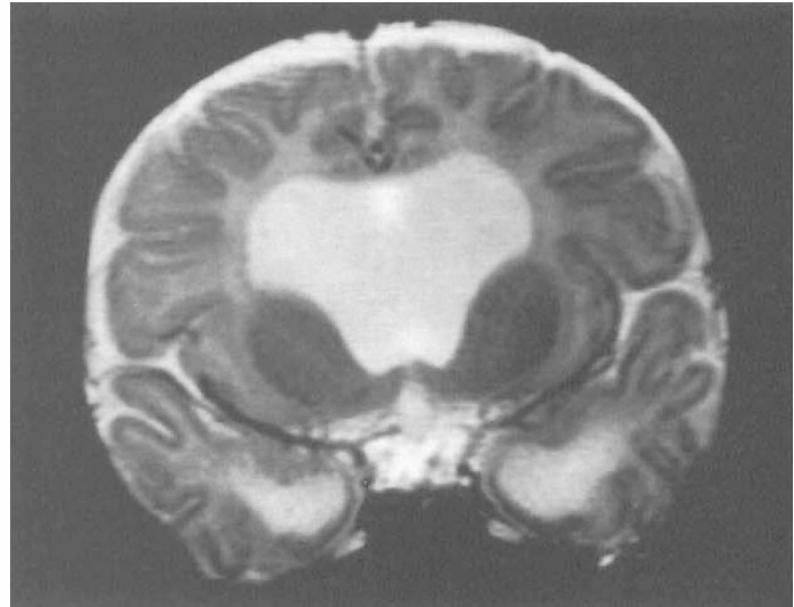

(b)

Fig. 1. Patient 4: a 7-month-old female infant with clinical anophthalmos bilaterally (group 1). (a) Axial CT scan. Both orbits contain remnant ocular tissue, and the intracranial space reveals a large optochiasmatic cistern and severe temporal lobe white matter hypoplasia with passive enlargement of the ventricular horns. (b) Coronal section, long TR MRI sequence (TE: $120 \mathrm{~ms}$; TR: $2000 \mathrm{~ms}$ ) showing absent septum pellucidum, abnormally thin corpus callosum, large temporal ventricular horns, large and abnormally shaped frontal ventricular horns (pointing downwards), paucity of cerebral white matter, and normal grey matter with sulci reaching almost to the ventricles - a typical finding in severe white matter

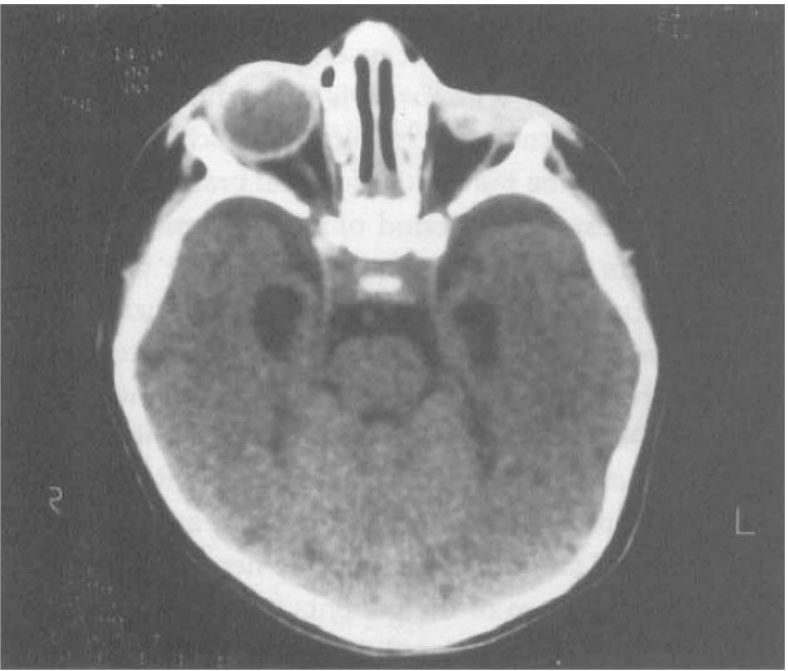

(a)

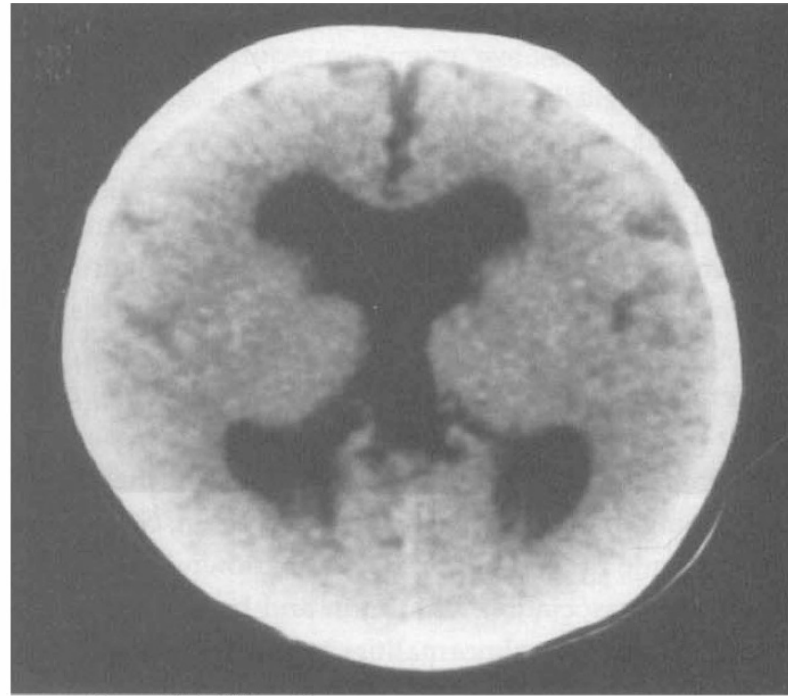

(b)

Fig. 2. Patient 8: a 2-week-old female infant. (a) Axial CT scan showing unilateral microphthalmos with bilateral small optic nerves (intraorbital segment) and temporal horn enlargement due to white matter hypoplasia (group 2). (b) Axial CT scan at the supratentorial level demonstrating absent septum pellucidum, abnormal corpus callosum (thin with splenium partially missing) and white matter hypoplasia with globally enlarged ventricular system.

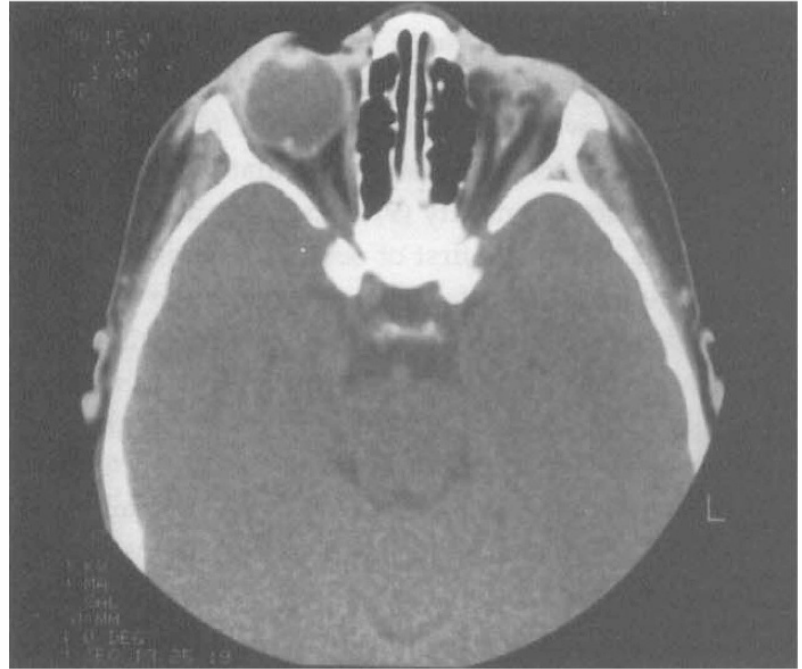

(a)

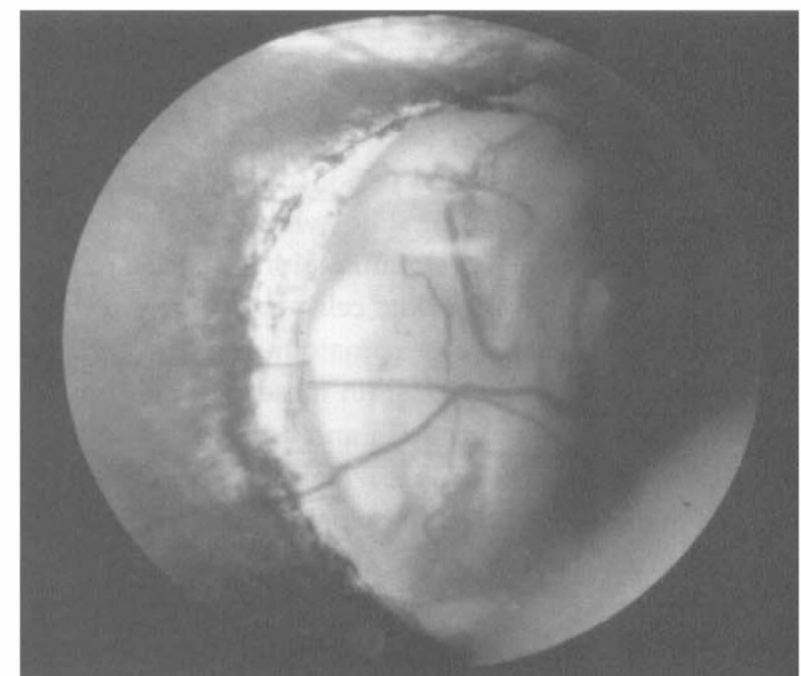

(b)

Fig. 3. Patient 16: a 6-year-old boy. (a) Axial CT scan showing left severe microphthalmos and right optic nerve coloboma (group 3). CNS structures appear normal. (b) Fundus photograph of right optic nerve coloboma. 
identified midline and hemispheric brain abnormalities, some of which might have serious implications for visual or cognitive potential or might require treatment in the future (e.g. hydrocephalus), in $71 \%$ of this series. CT scanning seems to be adequate to investigate anophthalmic and severely microphthalmic patients for treatable orbital and CNS anomalies. CT also offers the advantages of more rapid studies for this predominantly paediatric population, accurate assessment of orbital structure and volume, superior detection of brain calcifications, and wide availability throughout the world. CT technology clearly still has a place in conjunction with MRI in the investigation of these patients.

Several authors have stressed hormonal deficiencies and anatomical hypothalamic and pituitary abnormalities associated with microphthalmos, $, 6,21$ SOD, ${ }^{10,19,22}$ and optic nerve hypoplasia. ${ }^{12}$ Some SOD patients with hormonal abnormalities have potential risk under general anaesthesia. ${ }^{22}$ The only hormonal abnormality discovered in this patient series was an elevated prolactin level in 2 of 8 children tested (one in group 1 and one in group 3), possibly caused by decreased hypothalamic inhibition of prolactin release. Although not recognised in this patient series, it is possible that some anophthalmos patients with structural CNS abnormalities are at increased risk during general anaesthesia. This issue deserves consideration because general anaesthesia may be more common than usual in this patient population for cosmetic purposes such as insertion of orbital conformers and expandable prostheses.

\section{References}

1. Tucker S, Jones B, Collin R. Systemic anomalies in 77 patients with congenital anophthalmos or microphthalmos. Eye $1996 ; 10: 310-4$.

2. Warburg M. Classification of microphthalmos and coloboma. J Med Genet 1993;30:664-9.

3. Guyer DR, Green DR. Bilateral extreme microphthalmos. Ophthalmic Pediatr Genet 1984;4:81-92.

4. Elder MJ. Aetiology of severe visual impairment and blindness in microphthalmos. Br J Ophthalmol 1994;78:332-4.

5. Pallota R, Dallapiccola B. A syndrome with true anophthalmia, hand-foot defects, and mental retardation. Ophthalmic Pediatr Genet 1984;4:19-23.
6. Bierich JR, Christie M, Heinrich JJ, Martinez AS. New observations on midline defects: coincidence of anophthalmos, microphthalmos and cryptophthalmos with hypothalamic disorders. Eur J Pediatr 1991;150:246-9.

7. Ishikawa K, Sohmiya M, Ohguni S, Sato T, Tanigawa K, Kato $\mathrm{Y}$. Unique case of growth hormone $(\mathrm{GH})$ deficiency accompanied by clinical anophthalmia, hypoplastic orbits, digital dysplasia, short stature, obesity, and diabetes mellitus. Am J Med Genet 1996;67:191-6.

8. Moseley IF, Sanders MD. Anatomy. In: Computerised tomography in neuro-ophthalmology. 1st ed. Philadelphia: WB Saunders, 1982.

9. Cabanis EA, Bourgeois H, Iba-Zizen M-T. Les douze anatomies des voies visuelles in vivo. In: L'Imagerie en ophthalmologie. 1st ed. Paris: Masson, 1996:346-8.

10. Barkovich AJ, Fram EK, Norman D. Septo-optic dysplasia: MR imaging. Radiology 1989;171:189-92.

11. Manelfe C, Rochiccioli P. CT of septo-optic dysplasia. AJR 1979;133:1157-60.

12. Brodsky MC, Glasier CM. Optic nerve hypoplasia: clinical significance of associated central nervous system abnormalities on magnetic resonance imaging. Arch Ophthalmol 1993;111:66-74.

13. Barkovich AJ, Kjos BO. Normal postnatal development of the corpus callosum as demonstrated by MR imaging. Am J Neuroradiol 1988;9:487-91.

14. Noden DM. Periocular mesenchyme: neural crest and mesodermal interactions. In: Ocular anatomy, embryology, and teratology. Philadelphia: Harper and Row, 1982:91-119.

15. Barkovich AJ, Chuang SH, Norman D. MR of neuronal migration anomalies. AJR 1988;150:179-87.

16. Gorlin RJ, Pindborg JJ, Cohen MM. Syndromes of the head and neck. 3rd ed. New York: McGraw-Hill, 1989:641.

17. Wilson DM, Enzmann DR, Hintz RL, Rosenfeld G. Computed tomographic findings in septo-optic dysplasia: discordance between clinical and radioloical findings. Neuroradiology 1984;26:279-83.

18. Daxecker F, Felber S. Magnetic resonance imaging features of congenital anophthalmia. Ophthalmologica 1993;206:139-42.

19. Brodsky MC, Conte FA, Taylor D, Hoyt CS, Mrak RE. Sudden death in septo-optic dysplasia: report of 5 cases. Arch Ophthalmol 1997;115:66-70.

20. Kornreich L, Horev G, Lazar L, Schwarz M, Sulkes J, Pertzelan A. MR findings in growth hormone deficiency: correlation with severity of hypopituitarism. Am J Neuroradiol 1998;19:1495-9.

21. Brodsky MC, Frindik JP. Hypothalamic-hypophyseal dysgenesis as a neuroimaging correlate of pituitary hormone deficiency in anophthalmia. Am J Ophthalmol 1996;122:747-8.

22. Sherlock DA, McNicol LR. Anaesthesia and septo-optic dysplasia: implications of missed diagnosis in the perioperative period. Anaesthesia 1987;42:1302-5. 